\title{
視方向に対する標識の水平角が煙中の視認距離に与える影響 誘導灯及び案内標識の視認性
}

\section{THE EFFECT ON ACUTE YAW ANGLES WITH VIEW DIRECTION THROUGH FIRE SMOKE}

- Visibility of the emergency sign and the direction sign -

\author{
藤井皓介*, 佐野友紀**, 大宮喜文***
}

\section{Kosuke FUJII, Tomonori SANO and Yoshifumi OHMIYA}

\begin{abstract}
Two experiments on the visibility of a direction sign and three emergency signs through fire smoke were carried out with subjects. In Japanese railway stations, direction signs, which are prescribed by rules of each railway company, and Emergency signs, which are prescribed by Fire Services Act, are installed. The emergency signs used in the experiments are an evacuation exit sign and two evacuation route signs. Smoke density, type of signs and yaw angles of the sign were changed in the experiments. Twenty subjects aged twenties were participated in the experiments. All subjects have normal sight. The experiments are planned with "Design of Experiment". As a result of statistical analysis with regression analysis, relational expressions of each sign about the visible distance, smoke density and yaw angles were derived.
\end{abstract}

Keywords : Station, Evacuation, Smoke, Sign, Emergency Sign, Visibility 駅, 避難, 煙, 標識, 誘導灯, 視認性

\section{1. 序論}

\section{1 研究背景}

鉄道駅は運輸施設であるため、平常時の多数の利用者の移動を主 目的として計画されているが、利用者の非常時における動線計画は 平常時と異なる場合があり、非常時に配慮して避難経路を提示し、 利用者を適切に誘導することは必要不可欠である。避難経路の提示 方法については消防法により誘導灯注 ${ }^{1)}$ 及び誘導標識が規定されて いる。また、駅特有の経路表示設備として日常的に出口・経路を示 す案内標識が鉄道駅の基準に従い設置されている。両者はそれぞれ の基準で設置されているが、ともに出口方向を示すものであり、利 用者の避難経路選択に影響を与える可能性が考えられる。建築物と して避難経路選択に影響を与える可能性の高い誘導灯・案内標識の 影響を考慮した避難誘導が必要となる。

鉄道駅構内の誘導灯は、日常利用目的である案内標識と互いに視 認を阻害しない形で設置されている注2)。ただし、大規模鉄道駅のコ ンコースや通路では幅員が広いため、利用者の位置によって通路の 端から斜め正面方向誘導灯を見る場合や、狭い連絡通路等の側壁面 に設置された通路誘導灯を通路中央から見る場合には、避難者は表 示面に対して斜めから確認する場合が生じる。避難者が視認する角 度により誘導灯の見え方は異なるため、視認する角度を考慮して設 置することが望ましいが、視方向に対寸る誘導灯の水平角が視認距 離に与える影響に関する知見は少ない。

また、誘導灯の設置については、煙中において利用される可能性 があるため、煙中における誘導灯の使用を考慮する必要がある。

\section{2 既往研究}

煙中における誘導標識及び誘導灯の視認距離に関する研究として、 神 1)は、白黒標識を用いて異なる建材により発生する煙中における 標識の見透し距離の比較を行い、反射型標識と発光型標識のそれぞ れについて減光係数と見透し距離の積が一定範囲内にあることを明 らかにしている。上記関連研究として、神 2)は、標識の場所の事前 把握の有無が標識の輝度と標識の探索時間との関係を明らかにする とともに、刺激性煙の白煙と無刺激性煙の黒煙中における避難口誘 導灯の視認限界、色の識別限界、文字の判読限界それぞれの見透し 距離と煙濃度との関係を明らかにしている。神 3 )は、各種建材につ いて赤色と青色光を発する 2 種の標識の見透し距離を比較し、赤色 光の方が青色光に比べて見透し距離が大きいことを明らかにしてい る。同種研究として、山田ら ${ }^{4)}$ は、白煙中における新旧誘導灯の見 透し距離の比較を行い、新型 $\mathrm{B}$ 級誘導灯は旧型誘導灯に比べて効果 が高いことを明らかにしている。視認距離に限らず、誘導灯及び誘 導標識に関寸る研究が行われている。森山ら ${ }^{5)}$ は、大規模地下街に おいて通常照明、通路誘導灯、避難口誘導灯、店舗広告を変更して 避難経路選択実験を行い、誘導灯の理解の不足が避難出口の素通り 及び避難経路の長距離化に繋がることを示し、誘導灯を強調するこ との必要性を述べている。田中ら ${ }^{6}$ は、質問紙及びコンピュータを 用いた被験者実験により、避難出口通過後の情報を付加した避難口 誘導灯の単独避難者に対寸る効果について検証している。横石ら 7) は、健常者とインスタントシニアによる被験者実験により高輝度蓄 光式誘導標識設置下における避難時間及び避難時の安心感、経路の
* 早稲田大学大学院人間科学研究科 博士後期課程 · 修士 (人間科学)

** 早稲田大学人間科学学術院 准教授 ·博士 (工学)

*** 東京理科大学理工学部建築学科 教授. 博士 (工学)
Graduate School of Human Sciences, Waseda University, M.A. in Human Sciences

Faculty of Human Sciences, Waseda University, Dr. Eng.

Dept. of Architecture, Faculty of Science \& Technology, Tokyo University of Science, Dr. Eng. 
視認性について明らかにしている。秋月ら ${ }^{8)}$ は、旅客施設である空 港における避難経路上のサインの設置状況を、等距離射影方式の円 周魚眼レンズを用いた定点撮影後に射影方式の変換処理をした画像 を用いて求めたサインの立体角投射率を基に、誘導灯よりも広告の 視界に占める割合が多いことを示している。石井ら 9)は、表示面の 寸法が B 級に相当する高輝度誘導灯を作成し、背景輝度及び誘導灯 の輝度を変化させるとともに段階的に角度を回転させ、評価対象と なる誘導灯について基準となる誘導灯に対する比較評価を段階尺度 評定法により行うことで、輝度值と回転角の組み合せ毎に 300 $1200\left[\mathrm{~cd} / \mathrm{m}^{2}\right]$ の背景輝度下において消防法の設置限界距離から見た 際の誘導灯の有効性を回転角別に評価している。

平成 11 年の消防法改正に伴い新型誘導灯が導入され、各製造販 売会社で取り扱う誘導灯は新型に移行し、従来型の取り扱いは少な くなっている。このため、本研究では新型誘導灯を対象とするが、 新型誘導灯について煙中における視認性の観点から、視方向に対す る標識の水平角と視認距離の関係について把握した例は見られない。 本研究では、消防法により規定された誘導灯の視認性及び鉄道駅 での実測をもとに模擬的に作成した案内標識模型の視認性を、被験 者実験により把握するものである。煙中における人の視認に基づき、 煙濃度と水平角別の視距離の関係を把握する点において、新規性を 有すると考えられる。

\section{3 研究目的}

本研究は、消防法により規定される誘導灯及び鉄道駅の案内標識 模型について、設置空間の煙濃度、視方向に対寸る標識の水平角を 条件とした被験者実験により煙中における視認距離を把握すること で、煙の濃度・標識の種類・標識の設置状況が視認距離に与える影 響を明らかにする注3)。この結果を基に、火災避難時に活用し得る誘 導灯・案内標識について設置方法の指標とすることを目的とする。

\section{2. 研究方法}

\section{1 煙中の案内標識及び誘導灯の視認性実験}

本実験では、現行の誘導灯の内、最も視認距離の小さい高輝度 $\mathrm{C}$ 級誘導灯を基準、床面照度は駅舎通路を想定し、照明の種類を蛍光 灯、煙の種類を白煙として条件を設定した注 ${ }^{4)}$

本実験の目的は、煙濃度及び標識の水平角が視認距離に与える影 響を把握することである。実験条件となる標識の水平角は実験結果 を実務に反映させることを想定したため、度数法に基づき水準を設 定した。本研究では、水平角の水準を変更し 2 回の実験を実施した。 実験 1 (2011 年) において、水平角 $0^{\circ} \sim 60^{\circ}$ の間で視認距離に対 する影響に大きな差異は見られなかった。このため、実験 2（2012 年）では水平角の角度をより大きく $70^{\circ} 、 80^{\circ}$ を追加した。本実験 に用いた誘導灯は規定通りのものであり、案内標識は公式に寸法デ 一タ等が公開されていないため鉄道駅に実存する標識をもとに作成 した模型を利用した。鉄道駅に設置された案内標識の表示面に記載 されているピクトグラム及び文字の寸法を測定し、その比率を用い て表示面の縦幅を誘導灯に合わせている。

実験日時: 実験 12011 年 9 月 14 日 9:30 17:00 実験 22012 年 11 月 5,16 日 9:00 18:00

実験場所：東京理科大学 火災科学研究センター 実験棟 実験空間（図 1,2
被験者 : 20 歳代の大学生・大学院生 (視力 1.0 以上) 各実験 20 名 実験方法 : スモークジェネレータを用いて、スモーク液（表 1）を フォグマシーン(株式会社ギミック、Viper-NT、Slow Fog Fluid) により気化させることで実験空間内に白煙を発生させる。設定し た煙濃度に調整し、減光計により電圧を測定する。実験空間内の 煙は一様になる様、摚拌を行う。実験空間は設定した煙濃度に調

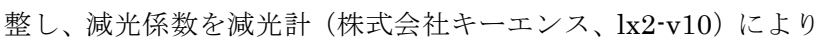
測定する。水平角は計画した実験試行毎の条件に従い、煙濃度調 整前に変更する。被験者 1 名あたりの試行回数（実験 $1: 8$ 回、 実験 $2: 10 \sim 11$ 回）及び実験順序は実験計画法により調整する。 被験者・実験者の各 1 名が、以下の (1) (5)を実験の総試行回数 分（実験 1:160 回、実験 2:210 回）繰り返す。(1)実験者が被験 者を実験室に誘導し、両者が 2 人 1 組となり実験室に入る。(2)被 験者をスタート位置に立たせ、教示を行う。(3)被験者が、標識を 認識できると申告する距離まで歩かせる。(4)被験者が立ち止まっ た位置と時刻を測定し被験者に質問をする。(5)質問に対して被験 者が誤答をした場合、被験者が立ち止まっている位置において誤 答をしたことを伝え、(3)(4)の手順を再度行う。(6)正答後、位置と 時刻を記録し、被験者を実験室から出す。

なお、標識の視認性を確認する方法として、誘導灯と案内標識 それぞれについて矢印の向き等を変更したパターンを含む複数の 表示面の例を紙面上に印刷した質問紙を用いた。被験者への質問 の際は、誘導灯と案内標識のそれぞれについて複数の例を提示し、 見えた誘導灯または案内標識と同じものを選択させた。

教示 : 正面に標識があります。標識の内容が分かる位置までまっす ぐ歩いて進んで下さい。分かる位置まで来たら、そこで立ち止ま り、横にいる被験者に「ここです。」と伝えて下さい。実験者が 標識について質問をするので、その質問に答えて下さい。

表 1 スモーク液の概要

\begin{tabular}{|c|c|c|}
\hline 製品名 & ロスコ & スモーク液スタンダード \\
\hline におい & & ほぼ無臭 \\
\hline 刺激性 & & 無し \\
\hline 大気中残存眭間 & & 約 10 分 \\
\hline
\end{tabular}

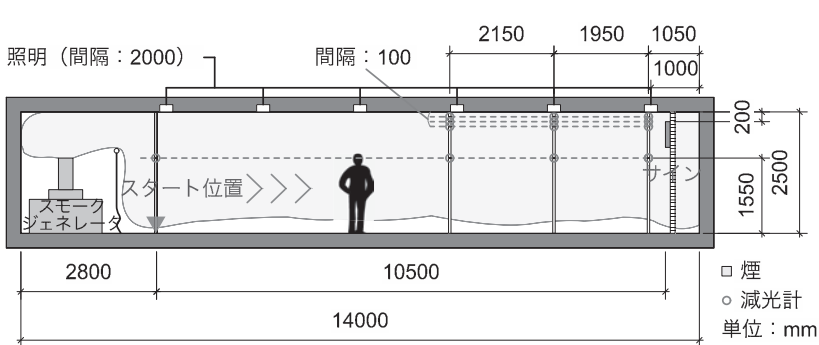

図 1 実験 1 実施状況及び器具配置（断面図）

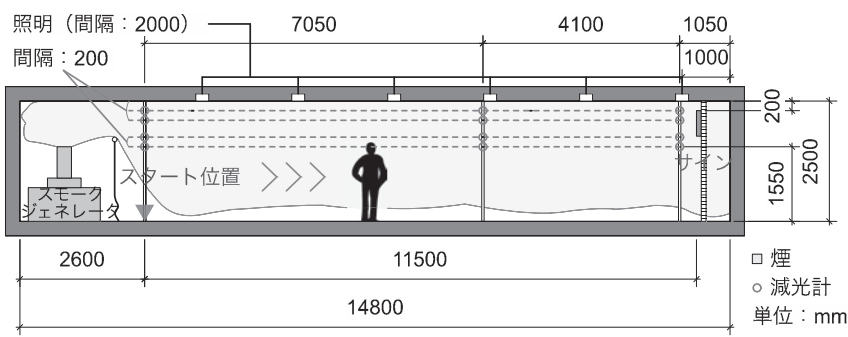

図 2 実験 2 実施状況及び器具配置（断面図） 
実験条件：実験条件は、以下の通りとする。

i )減光計の位置（図 1,2）

減光計の位置は、被験者の標識視認時における視線上の煙の 濃度を測定することを目的として設置した。高さは、目線及び 誘導灯の設置高さとなる天井付近とし、水平方向はスタート地 点、中央付近、誘導灯正面直近とした注 5) 1 回目は標識近傍に 多数、2 回目は 1 回目の結果をもとに必要数とした。

ii )煙の種類（表 1)

本実験では、倫理上の観点から人体に対する影響の少ない白 煙のみを使用した。各種建材により発生する煙は、刺激や臭い の点で人体への侵襲が大きい。このことから、火災訓練の煙体 験で用いられるスモーク液（ロスコ社製 スモーク液スタンダ ード）を気化させた白煙を用いることとした。

iii) 煙の濃度

各実験において設定した煙の濃度は以下の通りである。 実験 $1 「 レ$ ルル $1(\mathrm{Cs}=0.7) /$ レベル $2(\mathrm{Cs}=1.1) /$ レベル $3(\mathrm{Cs}=1.5) 」$

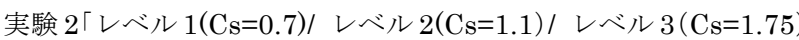
/ レベル $4(\mathrm{Cs}=2.5) 」$

なお、（）内は濃度調整時に目標とする減光係数 $\left[1 / \mathrm{m}^{2}\right]$ を示す。 iv) 天井照明「白色蛍光灯 (平均床面照度 $=1141 \mathrm{x}) 」$ 注 6) (図 1, 2)。

$20 \mathrm{w}$ 蛍光灯 2 本を壁から $2 \mathrm{~m}$ 間隔で均等に配置している。な お、上記測定値は煙のない状態における值である。

$\mathrm{v}$ )標識の種類「通路誘導灯（左方向）/通路誘導灯（両方向）/避 難口誘導灯/案内標識」注 7) (図 3,4)

誘導灯は、高輝度誘導灯 $\mathrm{C}$ 級を使用した。案内標識は、大規 模鉄道駅の案内標識の表示面に記載されているピクトグラム及 び文字の寸法を測定し、その比率を用いて表示面の縦幅を誘導 灯に合わせ作成した。また、案内標識表示面の言語は日本語の みとした。

vi)標識の水平角（表 2,3 , 図 5)

標識の水平角は以下の様に設定した。

実験 $1\left\ulcorner 0^{\circ} / 30^{\circ} / 60^{\circ} 」\right.$ 実験 $2\left\lceil 0^{\circ} / 60^{\circ} / 70^{\circ} / 80^{\circ}\right\rfloor$

\section{2 実験計画の作成}

本実験における試行順序は、実験計画法の一部実施要因計画を用 いて実験計画を行う。これにより、実験の効率化を図る。実験計画 法の使用に際し、統計解析ソフトウェア JMP9 Pro（SAS 社製）を 用い、最適化計画を実施する。

実験日をブロック因子とし、各実験日における被験者の無作為割 り付け（完全無作為化法）を基本とする。しかしながら、この場合 は標本として抽出した被験者毎の変動が考慮されない。被験者間要 因しかない場合、データ数と被験者数が等しくなるため、被験者の 効果は全水準の誤差に含まれる。被験者は視力に問題のない者を選 定しているが、個人差が視認距離に影響を与える可能性を考慮し、 被験者要因を設定し、被験者の個人差を水準として計画に含める。 被験者要因と煙濃度、標識、水平角の各要因における 1 次の交互作 用を考慮し、全要因について 2 要因間の交互作用項を設定する。他 の要因における偶然誤差から、被験者の個人差と交互作用それぞれ による効果を想定し、被験者要因を他 3 要因と計画上直交させる。 被験者の負担及び標識の設置・煙濃度の調整・水平角の変更に要 する時間を考慮し、被験者の参加時間帯（各 10 名）、標識、煙の濃
度、水平角の順に実験を分割する。被験者 1 名が各標識を確認する 回数は標識 1 種類あたり $2 \sim 3$ 回とし、その内、水平角は回毎に異 なる。これにより、被験者 1 名に対して標識と水平角の組み合せが 同一となる試行がなくなり、被験者の経験による効果が緩和される。

煙の大気中残存時間を考慮した摚拌のタイミングと実施体制等の 情報を加えたものを実験のタイムテーブルとする。

\section{3 減光係数の算出方法}

減光計で測定される電圧を基に減光係数の算出を行い、煙濃度の 数值化を行う。減光係数の算出は Lambert-Beer の法則により得ら れる式 $\mathrm{Cs}=(1 / \mathrm{d}) \times \ln \left(\mathrm{I}_{0} / \mathrm{I}\right)$ に基づく $(\mathrm{Cs}:$ 減光係数 $[1 / \mathrm{m}] 、 \mathrm{~d}:$ 減光 計のレーザー投光面から受光面までの距離 $[\mathrm{m}] 、 \mathrm{I}_{0}$ : 基準電圧 $[\mathrm{V}] 、 \mathrm{I}$ : 計測電圧 $[\mathrm{V}]{ }^{11}{ }^{11}$ 。本実験では、 $\mathrm{I}_{0}=5.0[\mathrm{~V}] 、 \mathrm{~d}=0.045[\mathrm{~m}]$ とする。

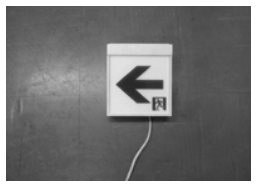

通路誘導灯（左方向）

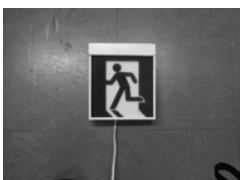

避難口誘導灯
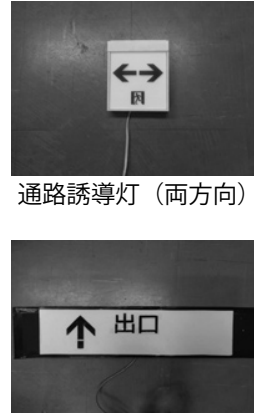

案内標識

図 3 標識の種類

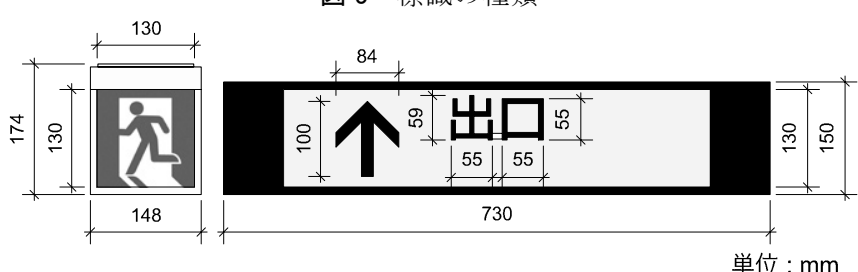

図 4 誘導灯及び案内標識の寸法

表 2 各実験における水平角の条件

\begin{tabular}{|c|c|c|c|c|c|}
\hline \multirow{2}{*}{} & \multicolumn{5}{|c|}{ 水平角 } \\
\cline { 2 - 6 } & $0^{\circ}$ & $30^{\circ}$ & $60^{\circ}$ & $70^{\circ}$ & $80^{\circ}$ \\
\hline 実験1 & $\bigcirc$ & $\bigcirc$ & $\bigcirc$ & - & - \\
\hline 実験2 & $\bigcirc$ & - & $\bigcirc$ & $\bigcirc$ & $\bigcirc$ \\
\hline
\end{tabular}

表 3 水平角と視認する誘導灯表示面面積の関係

\begin{tabular}{|c|c|c|c|c|c|}
\hline 水平角 $\left.{ }^{\circ}\right]$ & 0 & 30 & 60 & 70 & 80 \\
\hline 誘導灯の正対面積 $\left[\mathrm{m}^{2} \times 10^{-2}\right]^{*}$ & 1.690 & 1.460 & 0.845 & 0.578 & 0.293 \\
\hline $0^{\circ}$ に対する面積比 & 1.00 & 0.86 & 0.50 & 0.34 & 0.17 \\
\hline
\end{tabular}

*被験者が正対時に視認する誘導灯表示面の面積
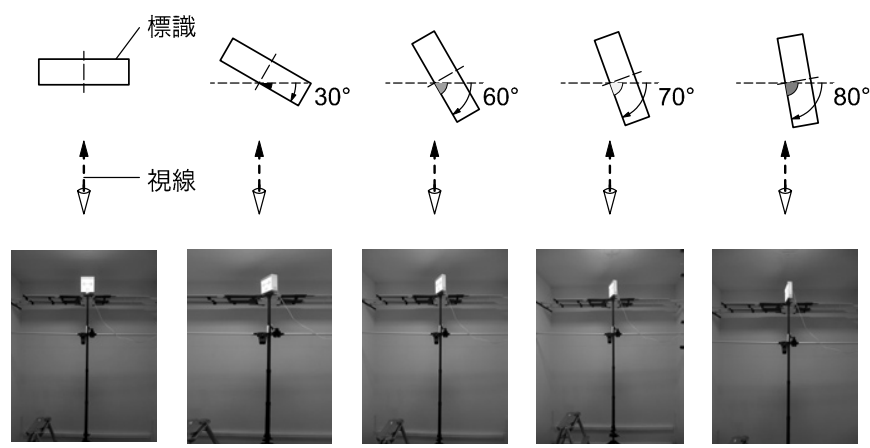

図 5 標識水平角の回転角度（俯瞰図） 


\section{3. 実験における煙濃度状態及び視認距離に対する個人差の把握}

\section{1 減光係数の分布傾向に基づく減光計の選定}

実験において使用した減光計の内、計測結果に異常が生じたもの を分析から除外する。除外は年度別に行い、減光係数の測定結果に 基づき機器の異常により近傍の機器との測定值がいちじるしく異な るものを除外した。以降の分析に用いる減光計として、実験 1 は計 7 台、実験 2 は計 11 台を選定した。減光計は、標識から異なる水平 距離間隔で 3 4 ケ所に設置しているが、選定した減光計は水平距 離上の各位置に設置されている。分散した場所で計測しており、ほ ぼ同様の值を示していることから、一様の煙の計測值としては妥当 と言える。

\section{2 視線上にある減光係数の導出}

実験 1 及び 2 のそれぞれについて、分析に用いる減光係数を導出 した注 ${ }^{8)}$ 。実験空間内の煙は可能な限り一様となる様に摚拌をしたこ とから、計測不良により除外したものを除くす心゙ての点について各 減光計の計測值を平均化したものを、視線上にある煙の減光係数の 代表値とし、以降の分析に用いる。

\section{3 被験者の個人差による影響の把握}

視認距離に対する被験者の個人差の影響について検討を行う。被 験者は変量因子として扱い、視力に問題のない集団から無作為抽出 された者とした。実験計画段階では被験者の個人差を想定し、要因 として設定した。被験者の単純主効果を調べるため、各実験日につ いて、被験者に対する視認距離の分散分析に基づく $\mathrm{F}$ 検定を行った 結果、いずれの実験日においても有意水準 $5 \%$ における有意差は見 られなかった。よって、以降の分析では個人差はないものとする。

\section{4. 視認距離の予測式の導出}

実験 1 及び実験 2 の結果それぞれについて、回帰式の導出を行う。 導出にあたり、線形関係を確保するため水平角を正対面積（被験者 が正対時に視認する標識表示面の面積）に換算して説明変数に用い る。水平角と正対面積の関係は $\mathrm{S}_{\mathrm{ha}}=\mathrm{S} \cos \theta \quad\left(\mathrm{S}_{\mathrm{ha}}\right.$ : 正対面積 $\left[\mathrm{m}^{2}\right]$, $\mathrm{S}$ : 標識表示面の面積 (内容記載部の方形面積) $\left[\mathrm{m}^{2}\right], \theta$ : 水平角 $\left.{ }^{\circ}\right]$ ) で表される。

実験 1 と 2 では、水平角と濃度の条件が異なるため、結果を統合 して分析した場合、視認距離・減光係数・正対面積の 2 変数の分布 に影響を与え、相関係数及び回帰式の予測精度に影響を与える可能 性がある。単一の年度について分析をした方が、分布に偏りがなく なり回帰モデルの形状を確実に把握できると考えられる。濃度と水 平角の範囲が広い実験 2 の結果に基づき回帰モデルを決定し、実験 1 及び実験 2 の結果を統合したデータに基づき予測式を導出する。

予測式の導出手順として、(1)全変数を用いた重回帰分析（最小 2 乗法)、(2)変数選択、(3)回帰診断（データ診断、構造診断、モデル診 断） 注9)を行う。(2)変数選択において、ステップワイズ法を用いる場 合、変数増減法を用いて最小 2 乗法において用いた説明変数から有 効な変数を選択して回帰式を求める。有効な変数の見落としを防ぐ ため、回帰係数の有意水準を $25 \%$ とする。(3)回帰診断では、(1) と (2) で得られた回帰モデルの評価を行う。

\section{1 回帰モデルの決定}

\subsection{1 変数間の相関}

視認距離を減光光係数、正対面積について標識毎に 2 変数毎の相 関分析を行う。いずれの標識においても、視認距離と平均減光係数 の間のみ無相関検定における有意確率が 0.05 未満、相関係数が-0.79 以下となる。上記 2 変数間のみ相関が見られる（表 $4 ） 。$

\subsection{2 直線回帰式の導出}

各標識について、減光係数及び正対面積に対する視認距離の最小 2 乗法による直線回帰式を求める。交互作用項を含める場合と含め ない場合について比較し、交互作用項の効果を検証する注 10)。

交互作用の有無に関わらず、有意水準 $5 \%$ において全標識につい て回帰式は統計的有意性を持ち、予測に役立つと言える。各標識の 自由度調整済み決定係数の変化は、交互作用項の投入前と比較して 最大 0.01 程度であり、交互作用項の投入による変化は少ない(表 5 )。

各標識について有意水準 $25 \%$ における交互作用項の統計的有意 性は異なる。交互作用項の投入前後で主効果の有意確率に大きな変 化は見られない。有意水準 $5 \%$ における統計的有意性は変化せず、 標準化偏回帰係数の差も小さい。交互作用項の効果は小さいと言え る。したがって、交互作用投入後において交互作用項を含めて全要 因の VIF が 1 程度となり要因の独立性は高いと考えられるが、直線 回帰において減光係数と正対面積間の交互作用は無視できる(表 6)。 続いて、回帰診断を行う。モデル診断の残差分析より、各標識に ついて減光係数に対するスチューデント化残差の散布図を見ると、 -1 次の曲線的な分布傾向が見られる。減光係数は-1 次の項とするこ とで回帰式に対する当てはまりが良くなると考えられる。

この検討により、予測式は直線ではなく減光係数を- 1 次とする曲 線 $(\mathrm{y}=1 / \mathrm{x})$ の式を用いることが適切であることが明らかとなった。

表 4 各標識における 2 変数間の相関係数(実験 2$)$

\begin{tabular}{|c|c|c|c|c|}
\hline & & 視認距離[m] & 減光係数 $[1 / \mathrm{m}]$ & 正対面積 $\left[\mathrm{m}^{2}\right]$ \\
\hline \multirow{3}{*}{$\begin{array}{c}\text { 通路誘導灯 } \\
\text { (左方向) }\end{array}$} & 視認距離[m] & 1.000 & $-0.794^{*}$ & 0.010 \\
\hline & 減光係数 $[1 / \mathrm{m}]$ & $-0.794^{*}$ & 1.000 & 0.226 \\
\hline & 正対面積 $\left[m^{2}\right]$ & 0.010 & 0.226 & 1.000 \\
\hline \multirow{3}{*}{$\begin{array}{c}\text { 通路誘導灯 } \\
\text { (両方向) }\end{array}$} & 視認距離 [m] & 1.000 & $-0.783^{*}$ & 0.012 \\
\hline & 減光係数 $[1 / \mathrm{m}]$ & $-0.783^{*}$ & 1.000 & 0.267 \\
\hline & 正対面積 $\left[m^{2}\right]$ & 0.012 & 0.267 & 1.000 \\
\hline \multirow{3}{*}{ 避難口誘導灯 } & 視認距離[m] & 1.000 & $-0.764^{*}$ & 0.029 \\
\hline & 減光係数 $[1 / \mathrm{m}]$ & $-0.764^{*}$ & 1.000 & 0.245 \\
\hline & 正対面積 $\left[\mathrm{m}^{2}\right]$ & 0.029 & 0.245 & 1.000 \\
\hline \multirow{3}{*}{ 案内標識 } & 視認距離 [m] & 1.000 & $-0.824^{*}$ & 0.093 \\
\hline & 減光係数 $[1 / \mathrm{m}]$ & $-0.824^{*}$ & 1.000 & 0.005 \\
\hline & 正対面積[m²] & 0.093 & 0.005 & 1.000 \\
\hline
\end{tabular}

表 5 交互作用項と直線回帰式の決定係数(実験 2)

\begin{tabular}{|c|c|c|c|c|c|}
\hline & $\begin{array}{c}\text { 交互作用項の } \\
\text { 有無 }\end{array}$ & $\begin{array}{l}\text { 自由度調整 } \\
\text { 決定係数 }\end{array}$ & $\begin{array}{l}\text { 誤差の標準 } \\
\text { 偏差(RSE) }\end{array}$ & F値 & 有意確率 \\
\hline \multirow{2}{*}{$\begin{array}{c}\text { 通路誘導灯 } \\
\text { (左方向) }\end{array}$} & なし & 0.655 & 1.466 & 49.431 & $<0.0001^{*}$ \\
\hline & あり & 0.664 & 1.447 & 34.607 & $<0.0001^{*}$ \\
\hline \multirow{2}{*}{$\begin{array}{c}\text { 通路誘導灯 } \\
\text { (両方) }\end{array}$} & なし & 0.651 & 1.180 & 49.600 & $<0.0001^{*}$ \\
\hline & あり & 0.645 & 1.190 & 32.557 & $<0.0001^{*}$ \\
\hline \multirow{2}{*}{ 避難口誘導灯 } & なし & 0.618 & 1.341 & 41.427 & $<0.0001^{*}$ \\
\hline & あり & 0.617 & 1.342 & 27.883 & $<0.0001^{*}$ \\
\hline \multirow{2}{*}{ 案内標識 } & なし & 0.676 & 1.487 & 54.164 & $<0.0001^{*}$ \\
\hline & あり & 0.679 & 1.481 & 36.923 & $<0.0001^{*}$ \\
\hline
\end{tabular}




\subsection{3 曲線回帰式の導出}

直線回帰式のモデル診断に基づき、減光係数の項を-1 次とし、各 標識について、減光係数及び正対面積に対する視認距離の最小 2 乗 法による曲線回帰式を求める。直線回帰と同様に、交互作用項の有 無が重回帰式に与える影響を検証する。

交互作用の有無に関わらず、有意水準 $5 \%$ において全標識につい て回帰式は統計的有意性を持ち、予測に役立つと言える。各標識の 自由度調整済み決定係数の変化は、交互作用項の投入前と比較して 最大 0.02 程度であり、交互作用項の投入による变化は少ない(表 7)。

交互作用項は、案内標識のみ有意水準 $25 \%$ における有意性が認め られない。交互作用項の投入前後で正対面積の有意確率が大きく変 化する。交互作用投入前において正対面積は案内標識の夕 $25 \%$ 水準 で有意とはならず、他 3 標識では有意となる。交互作用投入後、正 対面積の有意確率は全標識で上昇し、50\%以上となる。減光係数に ついては有意水準 $5 \%$ におる統計的有意性は変化せず、標準化偏 回帰係数の差も小さい。交互作用項の効果は小さいと言え、曲線回 帰での減光係数と正対面積間の交互作用は除外する（表 8)。

採択した回帰曲線について、回帰診断を行う。データ診断により 視認距離の残差が誤差の標準偏差（RMSE）の 2 倍を超えるデータ を外れ値とし、各データについて要因を把握した。濃度が薄い場合 に視認限界以上に近づくことが要因と考えられるものについて、分 析から除外した。構造診断により説明変数の選択を行ったところ、 案内標識のみ正対面積の偏回帰係数が有意水準 $25 \%$ を満たさず、除 外された。採択された重回帰モデルのVIF は全標識について 1 に近 似し、多重共線性はないと言える（表 9，10）。モデル診断として、 各標識の減光係数に対するスチューデント化残差の散布図を見ると、 直線回帰と比較して減光係数に対する分布の傾向が解消されている。

この検討により、予測式は減光係数と正対面積の主効果のみを説 明変数とすることが適切であることが明らかとなった。

表 6 交互作用項と直線回帰式の偏回帰係数 (実験 2)

\begin{tabular}{|c|c|c|c|c|c|c|}
\hline & \begin{tabular}{|l|} 
交互作用 \\
の有無
\end{tabular} & 項 & |偏回帰係数 $\mid$ & $\begin{array}{l}\text { 標集化 } \\
\text { 偏回帰係数 }\end{array}$ & 有意確率 & VIF \\
\hline \multirow{5}{*}{$\begin{array}{l}\text { 通路誘導灯 } \\
\text { (左方向) }\end{array}$} & \multirow{2}{*}{ なし } & 減光係数 $[1 / \mathrm{m}]$ & -1.738 & -0.839 & $<0.0001^{*}$ & 1.054 \\
\hline & & 正対面積 $\left[m^{2}\right]$ & 97.651 & 0.200 & $0.0221^{*}$ & 1.054 \\
\hline & \multirow{3}{*}{ あり } & 減光係数 $[1 / \mathrm{m}]$ & -1.843 & -0.890 & $\left\langle 0.0001^{*}\right.$ & 1.225 \\
\hline & & 正対面積 $\left[m^{2}\right]$ & 94.847 & 0.194 & $0.0244^{*}$ & 1.056 \\
\hline & & $\begin{array}{l}\text { (減光係数 }[1 / \mathrm{m}]-1.557) \times \\
\text { (正対面積 }\left[\mathrm{m}^{2}\right]-0.0084 \text { ) }\end{array}$ & 47.955 & 0.134 & 0.1349 & 1.182 \\
\hline \multirow{5}{*}{$\begin{array}{l}\text { 通路誘導灯 } \\
\text { (两方向) }\end{array}$} & \multirow{2}{*}{ なし } & 減光係数 $[1 / \mathrm{m}]$ & -1.825 & -0.846 & $<0.0001^{*}$ & 1.077 \\
\hline & & 正対面積 $\left[m^{2}\right]$ & 89.535 & 0.238 & $0.0072^{*}$ & 1.077 \\
\hline & \multirow{3}{*}{ あり } & 減光係数 $[1 / \mathrm{m}]$ & -1.859 & -0.861 & $\left\langle 0.0001^{*}\right.$ & 1.308 \\
\hline & & 正対面積 $\left[\mathrm{m}^{2}\right]$ & 88.503 & 0.235 & $0.0086^{*}$ & 1.084 \\
\hline & & $\begin{array}{l}\text { (減光係数 }[1 / \mathrm{m}]-1.447) \times \\
\text { (正対面積 }\left[\mathrm{m}^{2}\right]-0.0084 \text { ) }\end{array}$ & 12.844 & 0.036 & 0.6977 & 1.26 \\
\hline \multirow{5}{*}{ 避難口誘導灯 } & \multirow{2}{*}{ なし } & 減光係数[1/m] & -2.062 & -0.820 & $<0.0001^{*}$ & 1.064 \\
\hline & & 正対面 積 $\left[\mathrm{m}^{2}\right]$ & 95.688 & 0.229 & $0.0143^{*}$ & 1.064 \\
\hline & \multirow{3}{*}{ あり } & 減光係数 $[1 / \mathrm{m}]$ & -2.145 & -0.853 & $<0.0001^{*}$ & 1.218 \\
\hline & & 正対面積 $\left[\mathrm{m}^{2}\right]$ & 96.300 & 0.231 & $0.0139^{*}$ & 1.064 \\
\hline & & $\begin{array}{l}\text { (減光係数 }[1 / \mathrm{m}]-1.332) \times \\
\text { (正対面積 }\left[\mathrm{m}^{2}\right]-0.0087 \text { ) }\end{array}$ & 41.149 & 0.090 & 0.3411 & 1.151 \\
\hline \multirow{5}{*}{ 案内標識 } & \multirow{2}{*}{ なし } & 減光係数 $[1 / \mathrm{m}]$ & -2.402 & -0.825 & $<0.0001^{*}$ & 1.000 \\
\hline & & 正対面積 $\left[\mathrm{m}^{2}\right]$ & 22.573 & 0.097 & 0.2295 & 1.000 \\
\hline & \multirow{3}{*}{ あり } & 減光係数 $[1 / \mathrm{m}]$ & -2.486 & -0.853 & $\left\langle 0.0001^{*}\right.$ & 1.091 \\
\hline & & 正対面積 $\left[\mathrm{m}^{2}\right]$ & 22.346 & 0.096 & 0.2321 & 1.000 \\
\hline & & $\begin{array}{l}\text { (減光係数 }[1 / \mathrm{m}]-1.544) \times \\
\left.\text { (正対面積 }\left[\mathrm{m}^{2}\right]-0.0182\right)\end{array}$ & 24.443 & 0.100 & 0.2345 & 1.091 \\
\hline
\end{tabular}

表 7 交互作用項と曲線回帰式の決定係数 (実験 2)

\begin{tabular}{|c|c|c|c|c|c|}
\hline & $\begin{array}{c}\text { 交互作用項の } \\
\text { 有無 }\end{array}$ & $\begin{array}{l}\text { 自由度調整 } \\
\text { 決定係数 }\end{array}$ & \begin{tabular}{|l|} 
誤差の標準 \\
偏差(RMSE)
\end{tabular} & F値 & 有意確率 \\
\hline \multirow{2}{*}{$\begin{array}{c}\text { 通路誘導灯 } \\
\text { (左方向) }\end{array}$} & なし & 0.874 & 0.887 & 177.67 & $<0.0001^{*}$ \\
\hline & あり & 0.894 & 0.812 & 144.695 & $<0.0001^{*}$ \\
\hline \multirow{2}{*}{$\begin{array}{c}\text { 通路誘導灯 } \\
\text { (両方向) }\end{array}$} & なし & 0.729 & 1.041 & 70.8087 & $<0.0001^{*}$ \\
\hline & あり & 0.737 & 1.025 & 49.5715 & $<0.0001^{*}$ \\
\hline \multirow{2}{*}{ 避難口誘導灯 } & なし & 0.796 & 0.981 & 98.436 & $<0.0001^{*}$ \\
\hline & あり & 0.806 & 0.956 & 70.1654 & $<0.0001^{*}$ \\
\hline \multirow{2}{*}{ 案内標識 } & なし & 0.896 & 0.843 & 220.399 & $<0.0001^{*}$ \\
\hline & あり & 0.895 & 0.846 & 146.200 & $<0.0001^{*}$ \\
\hline
\end{tabular}

表 8 交互作用項と曲線回帰式の偏回帰係数 (実験 2)

\begin{tabular}{|c|c|c|c|c|c|c|}
\hline & $\begin{array}{l}\text { 交互作用 } \\
\text { の有無 }\end{array}$ & 項 & 偏回帰係数 & $\begin{array}{c}\text { 標集化 } \\
\text { 偏回帰係数 }\end{array}$ & 有意確率 & VIF \\
\hline \multirow{5}{*}{$\begin{array}{l}\text { 通路誘導灯 } \\
\text { (左方向) }\end{array}$} & \multirow{2}{*}{ なし } & 逆数(減光係数 $[1 / \mathrm{m}])$ & 4.639 & 0.964 & $<0.0001^{*}$ & 1.058 \\
\hline & & 正対面積 $\left[m^{2}\right]$ & 115.281 & 0.236 & $\left\langle 0.0001^{*}\right.$ & 1.058 \\
\hline & \multirow[b]{3}{*}{ あり } & 逆数(減光係数 $[1 / \mathrm{m}])$ & 4.740 & 0.985 & $<0.0001^{*}$ & 1.078 \\
\hline & & 正対面積 $\left[m^{2}\right]$ & 126.012 & 0.258 & 0.7099 & 1.08 \\
\hline & & $\begin{array}{c}\text { (逆数(減光係数 }[1 / \mathrm{m}])- \\
0.992588 \times\left(\text { 政対面積 }\left[\mathrm{m}^{2}\right]-\right. \\
0.0086) \\
0 .\end{array}$ & 144.716 & 0.149 & $0.0022^{*}$ & 1.033 \\
\hline \multirow{5}{*}{$\begin{array}{l}\text { 通路誘䆃灯 } \\
\text { (两方) }\end{array}$} & \multirow{2}{*}{ なし } & 逆数(減光係数 $[1 / \mathrm{m}]$ ) & 3.897 & 0.873 & $<0.0001^{*}$ & 1.032 \\
\hline & & 正対面積 $\left[\mathrm{m}^{2}\right]$ & 62.302 & 0.166 & $0.0284^{*}$ & 1.032 \\
\hline & \multirow[b]{3}{*}{ あり } & 逆数(減光係数 $[1 / \mathrm{m}])$ & 3.845 & 0.862 & $\left\langle 0.0001^{*}\right.$ & 1.042 \\
\hline & & 正対面積 $\left[m^{2}\right]$ & 69.670 & 0.185 & 0.6774 & 1.061 \\
\hline & & $\begin{array}{c}\text { (逆数(減光係数 }[1 / \mathrm{m}])- \\
0.9497) \times\left(\text { 正対面積 }\left[\mathrm{m}^{2}\right]-\right. \\
0.0086) \\
\end{array}$ & 100.212 & 0.117 & 0.1139 & 1.046 \\
\hline \multirow{5}{*}{ 避難口誘導灯 } & \multirow{2}{*}{ なし } & 逆数(減光係数 $[1 / \mathrm{m}])$ & 3.467 & 0.915 & $<0.0001^{*}$ & 1.042 \\
\hline & & 正対面積 $\left[m^{2}\right]$ & 88.586 & 0.212 & $0.0021^{*}$ & 1.042 \\
\hline & \multirow[b]{3}{*}{ あり } & 逆数(減光係数 $[1 / \mathrm{m}])$ & 3.479 & 0.918 & $\left\langle 0.0001^{*}\right.$ & 1.043 \\
\hline & & 正対面積 $\left[m^{2}\right]$ & 92.547 & 0.222 & 0.9228 & 1.049 \\
\hline & & 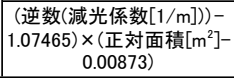 & 91.290 & 0.117 & 0.0686 & 1.007 \\
\hline \multirow{5}{*}{ 案内標識 } & \multirow{2}{*}{ なし } & 逆数(減光係数 $[1 / \mathrm{m}])$ & 5.621 & 0.946 & $\left\langle 0.0001^{*}\right.$ & 1.004 \\
\hline & & 正対面積 $\left[\mathrm{m}^{2}\right]$ & 7.142 & 0.031 & 0.501 & 1.004 \\
\hline & \multirow{3}{*}{ あり } & 逆数(減光係数 $[1 / \mathrm{m}])$ & 5.616 & 0.945 & $<0.0001^{*}$ & 1.005 \\
\hline & & 正対面積 $\left[m^{2}\right]$ & 7.247 & 0.031 & 0.6541 & 1.005 \\
\hline & & $\begin{array}{c}\text { (逆数(減光係数 }[1 / \mathrm{m}])- \\
0.87652 \times\left(\text { 政面積 }\left[\mathrm{m}^{2}\right]-\right. \\
0.01815) \\
0 .\end{array}$ & 20.833 & 0.037 & 0.4137 & 1.001 \\
\hline
\end{tabular}

表 9 回帰診断後の曲線回帰式の決定係数 (実験 2)

\begin{tabular}{|c|c|c|c|c|}
\hline & $\begin{array}{c}\text { 自由度調整 } \\
\text { 決定係数 }\end{array}$ & $\begin{array}{c}\text { 誤差の標準 } \\
\text { 偏差(RMSE) }\end{array}$ & F值 & 有意確率 \\
\hline $\begin{array}{c}\text { 通路誘導灯 } \\
\text { (左方向) }\end{array}$ & 0.902 & 0.786 & 232.130 & $<0.0001 *$ \\
\hline $\begin{array}{c}\text { 通路誘導灯 } \\
\text { (両方向 })\end{array}$ & 0.792 & 0.925 & 96.066 & $<0.0001 *$ \\
\hline 避難口誘導灯 & 0.873 & 0.725 & 162.969 & $<0.0001 *$ \\
\hline \hline 案内標識 & 0.923 & 0.740 & 584.387 & $<0.0001 *$ \\
\hline
\end{tabular}

表 10 回帰診断後の曲線回帰式の偏回帰係数 (実験 2)

\begin{tabular}{|c|c|c|c|c|c|}
\hline & 項 & 偏回帰係数 & $\begin{array}{c}\text { 標準化 } \\
\text { 偏回帰係数 }\end{array}$ & 有意確率 & VIF \\
\hline \multirow{2}{*}{$\begin{array}{c}\text { 通路誘導灯 } \\
\text { (左方向) }\end{array}$} & 逆数(減光係数 $[1 / \mathrm{m}])$ & 4.735 & 0.975 & $<0.0001^{*}$ & 1.050 \\
\cline { 2 - 7 } & 正対面積 $\left[\mathrm{m}^{2}\right]$ & 105.088 & 0.213 & $<0.0001^{*}$ & 1.050 \\
\hline $\begin{array}{c}\text { 通路誘導灯 } \\
\text { (两方向) }\end{array}$ & 逆数(減光係数 $[1 / \mathrm{m}])$ & 4.094 & 0.906 & $<0.0001^{*}$ & 1.026 \\
\cline { 2 - 7 } & 正対面積 $\left[\mathrm{m}^{2}\right]$ & 54.573 & 0.144 & $0.0320^{*}$ & 1.026 \\
\hline 避難口誘導灯 & 逆数(減光係数 $[1 / \mathrm{m}])$ & 3.482 & 0.953 & $<0.0001^{*}$ & 1.034 \\
\cline { 2 - 7 } & 正対面積 $\left[\mathrm{m}^{2}\right]$ & 73.356 & 0.190 & $0.0008^{*}$ & 1.034 \\
\hline \hline 案内標識 & 逆数(減光係数 $[1 / \mathrm{m}])$ & 5.812 & 0.961 & $<0.0001^{*}$ & - \\
\hline
\end{tabular}




\section{2 予測式の導出}

本研究では、現場において使用される各誘導灯及び案内標識の一 例について、それぞれの視認距離の予測式を導出する。これらの標 識は既存かつ表示内容の変更が少ないものであることから、ピクト グラム、文字や矢印などの個別要素を取り扱うのではなく、一体と しての視認距離を評価する。

\section{2.1 変数間の相関}

実験 $1 \cdot 2$ のデータより視認距離、減光係数、正対面積について 標識毎に 2 変数毎の相関分析を行う。全標識について視認距離と減 光係数について、無相関検定における有意確率が 0.05 未満、相関係 数が -0.67 以下となる。上記 2 変数間のみ相関が認められる(表 11$) 。$

\section{2.2 水平角と視認距離の関係}

各標識について、正対面積（水平角）に対する視認距離の関係を 把握する。ここでは、水平角の変化による視認距離の変化傾向を把 握するため、スタート地点において視認した場合の視認距離の值 （2011 年度：10.5m、2012 年度：11.5m）を分析に含めることと する。

同一濃度レベル下での視認距離の平均值より、いずれの標識も設 定濃度が濃くなるに従って、水平角 $0^{\circ}$ から $80^{\circ}$ に変化させた際の 視認距離の低下が小さくなることが読み取れる。ただし、誘導灯に ついてはレベル 3 と 4 において、案内標識についてはレベル 4 にお いて、水平角の変化に対する視認距離の減少は見られない。

誘導灯のレベル 1 と 2 、案内標識のレベル $1 \sim 3$ については水平角 の増加に従って視認距離の減少が認められる。誘導灯については、 通路誘導灯（左方向）及び通路誘導灯（両方向）のレベル 1 、避難 口誘導灯のレベル 1 と 2 において、案内標識ではレベル 1 ～ 3 にお いて、近い水平角間の視認距離の差が大きく $1 \mathrm{~m}$ 以上となる部分が ある。案内標識のレベル 1 については、 $60^{\circ}$ と $70^{\circ}$ 及び $70^{\circ}$ と $80^{\circ}$ の間、レベル 2 及び 3 については $60^{\circ}$ と $70^{\circ}$ の間において視認距 離に $1 \mathrm{~m}$ 以上の差が認められる。通路誘導灯（左方向）のレベル 1 については、 $30^{\circ}$ と $60^{\circ}$ の間に、通路誘導灯（両方向）のレベル 1 については、 $30^{\circ}$ と $60^{\circ}$ 及び $70^{\circ}$ と $80^{\circ}$ の間に認められる。避難 口誘導灯のレベル 1 については、 $60^{\circ}$ と $70^{\circ}$ の間に、レベル 2 に ついては $30^{\circ}$ と $60^{\circ}$ 及び $70^{\circ}$ と $80^{\circ}$ の間に認められる。

濃度が低い程、水平角の増加に伴う視認距離の減少が大きくなり、 濃度が高くなると水平角による視認距離の減少は見られなくなる。 特に誘導灯については、水平角が高くなるに従って、濃度間におけ る視認距離の差は小さくなる。視認距離、減光係数、正対面積（水 平角) を 2 変数間の関係で見た場合、減光係数と視認距離の夕相関 が認められるが、視認距離と水平角を濃度で分けた場合、濃度が低 い程両者の関係性が認められる。水平角と視認距離の関係に減光係 数が、減光係数と視認距離の関係に水平角が影響を与えている可能 性が考えられるが、水平角と減光係数には事象としての関係性はな く、回帰モデルの検討より交互作用項の効果は除外される。よって 視認距離に対して減光係数と正対面積（水平角）が独立して影響を 与えていると言える。
表 11 各標識における 2 変数間の相関係数 (2 実験統合)

\begin{tabular}{|c|c|c|c|c|}
\hline & & 視認距離[m] & 減光係数 $[1 / \mathrm{m}]$ & 正対面積 $\left[\mathrm{m}^{2}\right]$ \\
\hline \multirow{3}{*}{$\begin{array}{l}\text { 通路誘導灯 } \\
\text { (左方向) }\end{array}$} & 視認距離[m] & 1.000 & $-0.73^{*}$ & 0.135 \\
\hline & 減光係数 $[1 / \mathrm{m}]$ & $-0.73^{*}$ & 1.000 & 0.127 \\
\hline & 正対面積[m²] & 0.135 & 0.127 & 1.000 \\
\hline \multirow{3}{*}{$\begin{array}{l}\text { 通路誘導灯 } \\
\text { (両方向) }\end{array}$} & 視認距離[m] & 1.000 & $-0.673^{*}$ & 0.110 \\
\hline & 減光係数 $[1 / \mathrm{m}]$ & $-0.673^{*}$ & 1.000 & $0.299^{*}$ \\
\hline & 正対面積 $\left[m^{2}\right]$ & 0.110 & $0.299^{*}$ & 1.000 \\
\hline \multirow{3}{*}{ 避難口誘導灯 } & 視認距離[m] & 1.000 & $-0.697^{*}$ & 0.116 \\
\hline & 減光係数 $[1 / \mathrm{m}]$ & $-0.697^{*}$ & 1.000 & $0.244^{*}$ \\
\hline & 正対面積[m²] & 0.116 & $0.244^{*}$ & 1.000 \\
\hline \multirow{3}{*}{ 案内標識 } & 視認距離[m] & 1.000 & $-0.765^{*}$ & 0.204 \\
\hline & 減光係数 $[1 / \mathrm{m}]$ & $-0.765^{*}$ & 1.000 & -0.008 \\
\hline & 正対面積[m²] & 0.204 & -0.008 & 1.000 \\
\hline
\end{tabular}

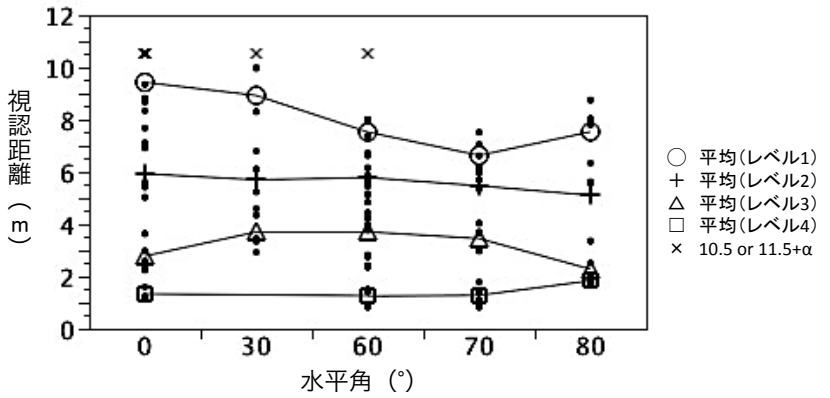

通路誘導灯 (左方向)

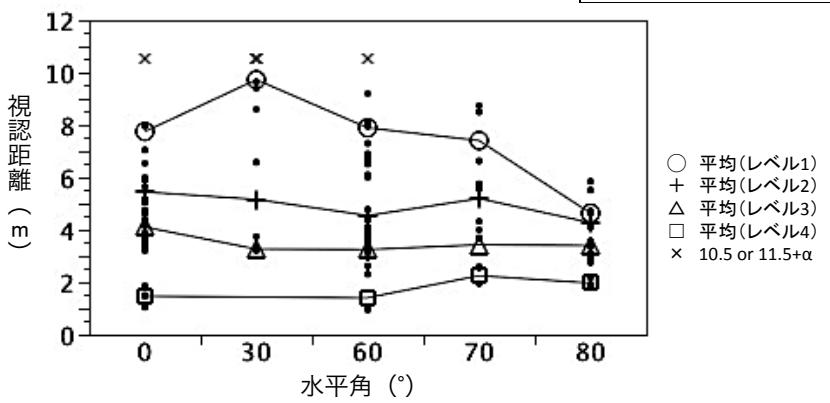

通路誘導灯（両方向）

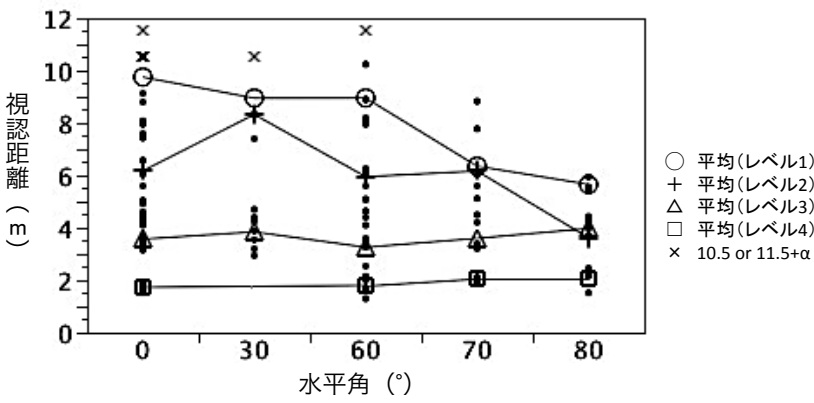

避難口誘導灯

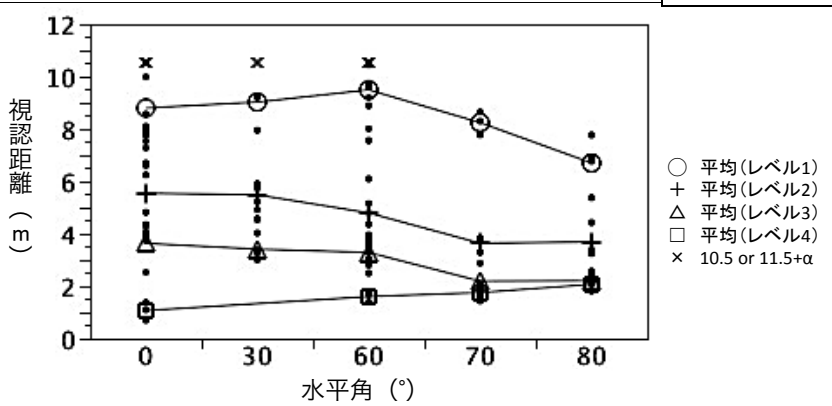

案内標識

図 6 濃度条件毎の水平角と視認距離の関係（2 実験統合） 


\section{2.3 予測式の導出}

実験 1 及び実験 2 の実験結果を統合し、予測式の導出を行う。実 験 2 の実験結果に基づき導出した重回帰式より、求める予測式の回 帰モデルを決定した。各標識について、減光係数及び正対面積に対 する視認距離の最小 2 乗法による曲線回帰式を求める。説明変数を 減光係数と正対面積の 2 変数とし、減光係数を -1 次の項とする。

全標識について決定係数は有意水準 $5 \%$ における統計的有意性を 持ち、予測に役立つと言える。自由度調整済み決定係数が 0.5 以上 となり、回帰式の精度はある程度認められる（表 12）。

全標識について、減光係数及び正対面積の偏回帰係数に対する有 意確率は $5 \%$ 未満となり、 $25 \%$ 水準及び $5 \%$ 水準のいずれについても 統計的有意性を持つ。標準化偏回帰係数において減光係数が正対面 積の 2〜4 倍となり、実験 2 の最終モデルにおける 4 〜倍に対して 正対面積の回帰式に対する影響が大きくなる（表 13）。

以上の回帰式について、回帰診断を行う。データ診断により視認 距離の残差が誤差の標準偏差（RMSE）の 2 倍を超えるデータを外 れ值とし、各データについて要因を把握した。濃度が薄い場合に視 認限界以上に近づくことが要因と考えられるものについて、分析か ら除外した。構造診断において、採択された重回帰モデルのVIF は 全標識について 1 に近似し多重共線性はないと言える(表 14,15 )。 モデル診断の残差分析より、各標識について 2 説明変数に対するス チューデント化残差の散布図において、分布に傾向は見られない。

各標識について正対面積と減光係数に基づく視認距離の予測式を 以下に示す $\left(\mathrm{L}\right.$ : 視認距離 $[\mathrm{m}], \mathrm{Cs}$ : 減光係数 $[1 / \mathrm{m}], \mathrm{S}_{\mathrm{ha}}(=\mathrm{S} \cos$ $\theta)$ : 正対面積 $\left[\mathrm{m}^{2}\right], \mathrm{S}$ : 標識表示面の面積（内容記載部の方形面積） $\left[\mathrm{m}^{2}\right], \theta$ : 水平角 $\left.{ }^{\circ}\right]$ ) (表 15$)$ 。

通路誘導灯 (左方向) : $\mathrm{L}=-0.81+4.38 / \mathrm{Cs}+142.00 \cdot \mathrm{S}_{\mathrm{ha}} \cdot \cdot$ 式(1) 通路誘導灯（両方向）: $L=-0.07+3.78 / C s+114.61 \cdot S_{\mathrm{ha}} \cdot \cdot$ 式(2) 避難口誘導灯 $\quad: \mathrm{L}=-0.59+3.68 / \mathrm{Cs}+137.19 \cdot \mathrm{S}_{\mathrm{ha}} \cdot \cdot$ 式(3) 案内標識 $\quad: L=-0.97+5.38 / C s+50.61 \cdot S_{h a} \cdot \cdot$ 式(4)

上式は正対時の面積 $\mathrm{S}_{\mathrm{ha}}$ を水平角 $\theta$ と標識表示面の面積 $\mathrm{S}$ に分解 できる $\left(\mathrm{S}_{\mathrm{ha}}=\mathrm{S} \cos \theta\right)$ 。これにより、表示面の面積と水平角の代入 により視認距離を求めることができる。また、水平角の回転時に表 示面の縦幅は一定值である。縦幅を定数として予測式の傾き(偏回帰 係数)に含めることで右辺の単位系が $[\mathrm{m}]$ で統一され左辺と一致する。 各標識における減光係数と視認距離の関係と水平角を固定した予 測式を $0^{\circ} 、 60^{\circ} 、 80^{\circ}$ について示寸 (図 7)。予測式から、水平角 度が大きくなるに従い、視認距離が長くなる傾向が見て取れる。

\section{5. 結論}

\section{1 考察}

本報で導出した予測式(1)〜 (4) は、条件を限定した実験に基づくも のである。予測式は、実験条件である減光係数 $0.7 \sim 2.5[1 / \mathrm{m}]$ 及び水 平角 $0^{\circ} \sim 80^{\circ}$ の範囲で得たものであり、当該範囲における信頼性 が最も高いと考えられる。しかしながら、避難計画に適用するに当 たり、減光係数について、より大きな範囲で適応できること及び実 際の状況と対応した数值と関連づけて把握することが望ましい。予 測式の適応範囲について以下に述べる。

\subsection{1 減光係数の下限值}

予測式(1)〜(4)については、煙の濃度による視認性への影響を減光 係数の項により説明している。表示内容の視認には距離によるもの、 すなわち視力の限界により視認できなくなる要因と、煙の阻害によ り視認できなくなる要因が考えられる。本予測式は、この視力によ る距離の限界を超えない範囲内で行った実験に基づき導出している ため、視力限界については反映していない。

本研究に先立ち、誘導灯及び案内標識の予備的な実験により無煙 時 $(=0[1 / \mathrm{m}])$ において水平角を $0^{\circ} \sim 80^{\circ}$ とした時に、消防法に おいて避難口誘導灯の設置限界距離として定められている、誘導灯 から $15 \mathrm{~m}$ の地点で視認できることを確認している。このため、前提 として視認距離の限界は $15 \mathrm{~m}$ 以上であると言える。視認距離 $15 \mathrm{~m}$ 以下において本予測式により求められる視認距離は妥当と言える。 ここでは、視認距離 $15 \mathrm{~m}$ の時に求められる減光係数を、本予測式の 減光係数の下限值とし、これを求めることとする。

表 12 回帰式の決定係数 (2 実験統合)

\begin{tabular}{|c|c|c|c|c|}
\hline & $\begin{array}{c}\text { 自由度調整 } \\
\text { 決定係数 }\end{array}$ & $\begin{array}{c}\text { 誤差の標準 } \\
\text { 偏差(RMSE) }\end{array}$ & F值 & 有意確率 \\
\hline $\begin{array}{c}\text { 通路誘導灯 } \\
\text { (左方向 })\end{array}$ & 0.593 & 1.497 & 61.482 & $<0.0001 *$ \\
\hline $\begin{array}{c}\text { 通路誘導灯 } \\
(\text { (画方向 })\end{array}$ & 0.532 & 1.390 & 50.918 & $<0.0001 *$ \\
\hline 避難口誘導灯 & 0.557 & 1.486 & 54.525 & $<0.0001 *$ \\
\hline \hline 案内標識 & 0.655 & 1.497 & 79.723 & $<0.0001 *$ \\
\hline
\end{tabular}

表 13 回帰式の偏回帰係数 (2 実験統合)

\begin{tabular}{|c|c|c|c|c|c|}
\hline & 項 & 偏回帰係数 & $\begin{array}{c}\text { 標準化 } \\
\text { 偏回帰係数 }\end{array}$ & 有意確率 & VIF \\
\hline \multirow{2}{*}{$\begin{array}{c}\text { 通路誘導灯 } \\
\text { (左方向) }\end{array}$} & 逆数(減光係数) $[1 / \mathrm{m}]$ & 3.286 & 0.775 & $<0.0001^{*}$ & 1.018 \\
\hline & 正対面積 $\left[m^{2}\right]$ & 101.827 & 0.217 & $0.0029^{*}$ & 1.018 \\
\hline \multirow{2}{*}{$\begin{array}{c}\text { 通路誘導灯 } \\
\text { (両方 }\end{array}$} & 逆数(減光係数) $[1 / \mathrm{m}]$ & 3.528 & 0.764 & $<0.0001^{*}$ & 1.101 \\
\hline & 正対面積 $\left[m^{2}\right]$ & 129.995 & 0.341 & $<0.0001^{*}$ & 1.101 \\
\hline \multirow{2}{*}{ 避難口誘導灯 } & 逆数(減光係数) $[1 / \mathrm{m}]$ & 3.525 & 0.787 & $\left\langle 0.0001^{*}\right.$ & 1.117 \\
\hline & 正対面積 $\left[m^{2}\right]$ & 160.211 & 0.370 & $<0.0001^{*}$ & 1.117 \\
\hline \multirow{2}{*}{ 案内標識 } & "逆数(減光係数) $[1 / \mathrm{m}]$ & 4.911 & 0.789 & $\overline{\angle 0.0001^{*}}$ & 1.001 \\
\hline & 正対面積 $\left[m^{2}\right]$ & 52.218 & 0.229 & $0.0007^{*}$ & 1.001 \\
\hline
\end{tabular}

表 14 回帰診断後の回帰式の決定係数 (2 実験統合)

\begin{tabular}{|c|c|c|c|c|}
\hline & $\begin{array}{c}\text { 自由度調整 } \\
\text { 決定係数 }\end{array}$ & $\begin{array}{c}\text { 誤差の標準 } \\
\text { 偏差(RMSE) }\end{array}$ & F值 & 有意確率 \\
\hline $\begin{array}{c}\text { 通路誘導灯 } \\
\text { (左方向 })\end{array}$ & 0.717 & 1.204 & 100.854 & $<0.0001 *$ \\
\hline $\begin{array}{c}\text { 通路誘導灯 } \\
\text { (画方向 })\end{array}$ & 0.645 & 1.128 & 76.382 & $<0.0001 *$ \\
\hline 避難口誘導灯 & 0.734 & 1.069 & 107.356 & $<0.0001 *$ \\
\hline \hline 案内標識 & 0.782 & 1.144 & 142.953 & $<0.0001 *$ \\
\hline
\end{tabular}

表 15 回帰診断後の回帰式の偏回帰係数 (2 実験統合)

\begin{tabular}{|c|c|c|c|c|c|}
\hline & 項 & 偏回帰係数 & $\begin{array}{c}\text { 標準化 } \\
\text { 偏回帰係数 }\end{array}$ & 有意確率 & VIF \\
\hline \multirow{2}{*}{$\begin{array}{c}\text { 通路誘導灯 } \\
\text { (左方向) }\end{array}$} & 逆数(減光係数) $[1 / \mathrm{m}]$ & 4.382 & 0.887 & $<0.0001^{*}$ & 1.092 \\
\hline & 正対面積 $\left[m^{2}\right]$ & 142.002 & 0.314 & $<0.0001^{*}$ & 1.092 \\
\hline \multirow{2}{*}{$\begin{array}{c}\text { 通路誘導灯 } \\
\text { (両方向) }\end{array}$} & 逆数(減光係数) $[1 / \mathrm{m}]$ & 3.782 & 0.846 & $<0.0001^{*}$ & 1.103 \\
\hline & 正対面積 $\left[m^{2}\right]$ & 114.607 & 0.326 & $<0.0001^{*}$ & 1.103 \\
\hline \multirow{2}{*}{ 避難口誘導灯 } & 逆数(減光係数) $[1 / \mathrm{m}]$ & 3.676 & 0.903 & $<0.0001^{*}$ & 1.107 \\
\hline & 正対面積 $\left[m^{2}\right]$ & 137.192 & 0.347 & $<0.0001^{*}$ & 1.107 \\
\hline \multirow{2}{*}{ 案内標識 } & 逆数(減光係数) $[1 / \mathrm{m}]$ & 5.380 & 0.870 & 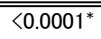 & 1.003 \\
\hline & 正対面積 $\left[m^{2}\right]$ & 50.607 & 0.232 & $<0.0001^{*}$ & 1.003 \\
\hline
\end{tabular}

は有意水準 $5 \%$ で有意となることを示す 
また、これと合わせて建物に不慣れな人が避難を始める減光係数 は $0.1[1 / \mathrm{m}]$ 程度 ${ }^{13)}$ 注 11 、建物をよく知っている人でも避難に支障が 出る減光係数は $0.3[1 / \mathrm{m}]^{13)}$ 注 ${ }^{11)}$ 程度であることが知られているた め、これらの状況における視認性について考察する。

予測式(1) (4)において水平角 $0^{\circ} 、 60^{\circ} 、 80^{\circ}$ のそれぞれにおけ る視認距離 $15 \mathrm{~m}$ の時の各標識の減光係数を求めると、通路誘導灯 （左方向）は $0.33 、 0.30 、 0.28[1 / \mathrm{m}]$ 、通路誘導灯（両方向）は 0.29 、 $0.27 、 0.26[1 / \mathrm{m}]$ 、避難口誘導灯は $0.28 、 0.25 、 0.24[1 / \mathrm{m}]$ 、案内標 識は $0.38 、 0.36 、 0.34[1 / \mathrm{m}]$ となる。すなわち、これらの減光係数の 值以下の煙濃度であれば視認可能となる。

不慣れな人が避難し始めるとされる減光係数 $0.1[1 / \mathrm{m}] 13)$ におい て、標識の種類、水平角に関わらず $15 \mathrm{~m}$ からすべてが視認できるこ とが確認できる。建物をよく知っている人でも避難に支障が出ると される減光係数 $0.3[1 / \mathrm{m}]^{13}$ ) では、通路誘導灯（左方向）の $70^{\circ}$ 及び $80^{\circ}$ と通路誘導灯（両方向）及び避難口誘導灯の全水平角において、 $15 \mathrm{~m}$ からは視認できないことが示唆される。また、案内標識は誘導 灯に対して遠い距離から視認可能であることが分かる。

以上より、減光係数を予測式に代入した際、視認距離が $15 \mathrm{~m}$ 以下 となり視認距離を精度よく算出できる減光係数の下限值は、通路誘 導灯（左方向）で $0.33[1 / \mathrm{m}]$ 以上、通路誘導灯（両方向）で $0.29[1 / \mathrm{m}]$ 以上、避難口誘導灯で $0.28[1 / \mathrm{m}]$ 以上、案内標識で $0.38[1 / \mathrm{m}]$ 以上と なる。視認距離が $15 \mathrm{~m}$ を超える場合は予測式の精度に配慮し、少な くとも視認距離は $15 \mathrm{~m}$ 以上であることを確認することができる。

\section{1 .2 消防法の有効範囲において誘導灯を視認できる減光係数}

消防法における $\mathrm{C}$ 級誘導灯の有効範囲は通路誘導灯が $10 \mathrm{~m}$ 、避難 口誘導灯が $15 \mathrm{~m}$ と定められている。各視認距離を予測式(1)〜(3)に 代入すると、水平角 $0^{\circ}$ においてこれらの距離が視認可能となる減 光係数の最大值は、通路誘導灯（左方向）が $0.52[1 / \mathrm{m}]$ 、通路誘導 灯（両方向）が $0.47[1 / \mathrm{m}]$ 、避難口誘導灯が $0.28[1 / \mathrm{m}]$ となる。この 減光係数以下であれば、基準の距離で標識を正面から視認すること が可能である。

\subsection{3 減光係数及び水平角の視認距離に対する影響度}

各標識の予測式(1)～(4)における正対面積の標準化偏回帰係数を 減光係数と比較すると、通路誘導灯（左方向）は 0.35 倍、通路誘導 灯（両方向）は 0.39 倍、避難口誘導灯は 0.38 倍、案内標識は 0.27 倍となる(表 15)。上記倍数は減光係数の視認距離に対する影響度を 1 とした時の正対面積 (水平角) の影響度を示す。水平角と比較し て煙濃度の方が誘導灯の視認距離に与える影響が高いことが分かる。

予測式(1)〜(4)に正対面積を代入して正対面積の項（水平角の項） を視認距離に換算すると、最大（水平角 $0^{\circ}$ ) で $2 \mathrm{~m}$ 前後となる。 また、最大 (水平角 $0^{\circ}$ ) と最小（水平角 $80^{\circ}$ ) の差は通路誘導灯 （左方向）で $2.0 \mathrm{~m}$ 、通路誘導灯（両方向）で $1.6 \mathrm{~m}$ 、避難口誘導灯 で $1.9 \mathrm{~m}$ 、案内標識で $1.5 \mathrm{~m}$ となる。水平角によって煙中での視認性 に $1.5 \mathrm{~m} \sim 2 \mathrm{~m}$ の差が生じることから、水平角が避難時の視認性に影 響を与えることが分かる。

各誘導灯の予測式(1) (3)における減光係数の偏回帰係数を比較 寸ると、通路誘導灯 (左方向) が最も高く、通路誘導灯（両方向） と避難口誘導灯が続く（表 15）。減光係数は-1 次の項であるため、
偏回帰係数はその值が高い程、減光係数の増加に対する視認距離の 減少が大きいことを示す。各誘導灯について、水平角及び減光係数 が同じ状態でそれぞれ誘導灯を視認できる距離に人を立たせた場合、 減光係数を増加させると立たせた位置からの視認距離の減少量は上 記の順になる。

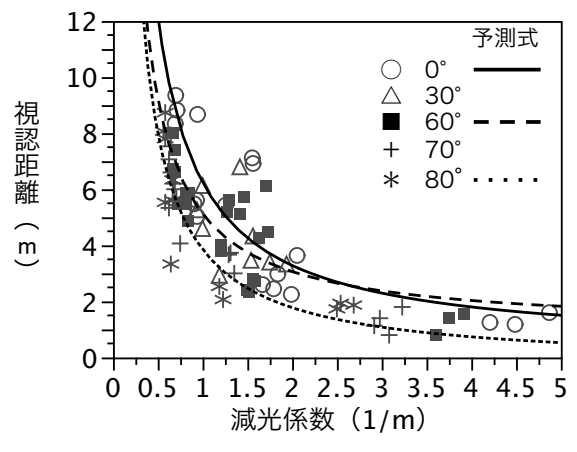

通路誘導灯 (左方向)

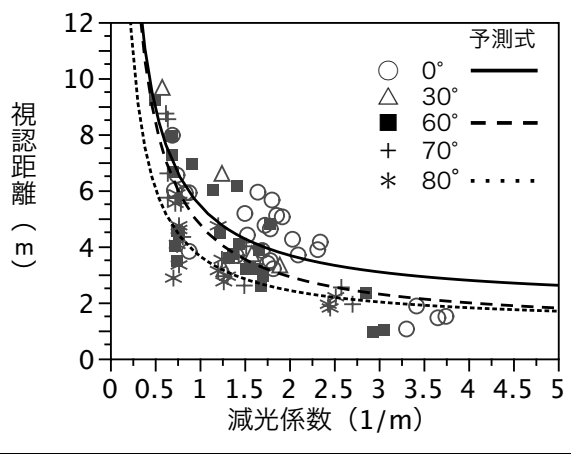

通路誘導灯 (両方向)

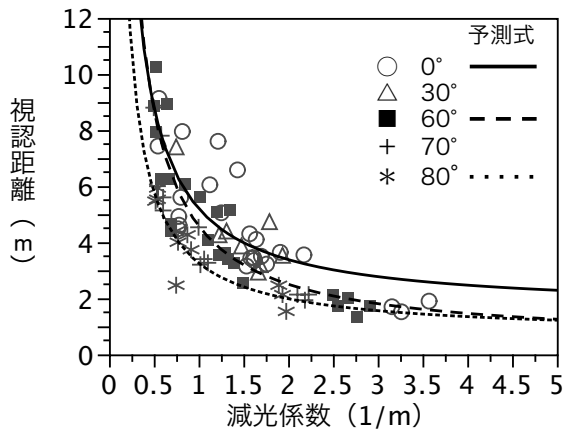

避難口誘導灯

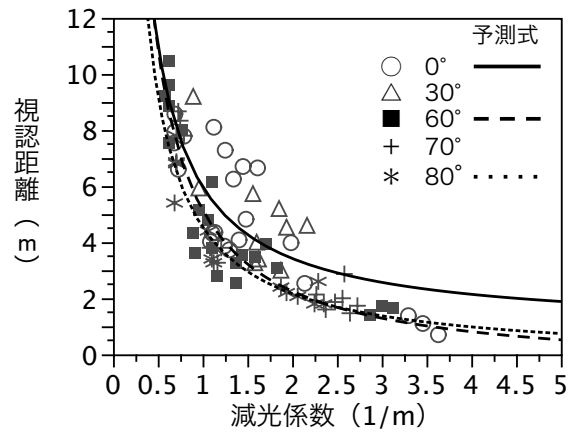

案内標識

図 7 水平角毎の減光係数と視認距離の関係（2 実験統合） 
各誘導灯の予測式(1)〜 (3)における正対面積の偏回帰係数を比較 すると、值の高い順に通路誘導灯（左方向）、避難口誘導灯、通路誘 導灯（両方向）となる（表 15）。偏回帰係数はその值が大きい程、 正対面積の減少、寸なわち水平角の増加に対する視認距離の減少が 大きいことを示す。各誘導灯について、水平角及び減光係数が同じ 状態でそれぞれ誘導灯を視認できる距離に人を立たせた場合、水平 角を増加（正対面積を減少）させると立たせた位置からの視認距離 の減少量は上記の順になる。

以上より、減光係数と水平角の両方について、視認距離に対する 影響を最も受け易いのは通路誘導灯 (左方向) である。減光係数に ついては通路誘導灯（両方向）と避難口誘導灯が続いて影響を受け 易い。水平角については、避難口誘導灯の受ける影響は通路誘導灯 （左方向）と同程度であり、通路誘導灯（両方向）が最も影響を受 け難い。なお、案内標識は通路誘導灯 (左方向) より減光係数の影 響が大きく、全誘導灯より水平角の影響が小さい。

\section{2 まとめ}

本研究は、煙の濃度・標識の種類・標識の視方向に対する水平角 が視認距離に与える影響を基に標識の配置指標を作成することを目 的とし、被験者実験を行うことで誘導灯及び案内標識模型について 視認距離に対する減光係数と水平角の影響を把握した。結果として、 各標識について減光係数と水平角を用いた視認距離の予測式を得た。

- 本実験の結果から各標識について水平角から得られる正対面積と 減光係数に基づく視認距離の予測式を得た $(\mathrm{L}$ : 視認距離 $[\mathrm{m}], \mathrm{Cs}$ : 減光係数 $[1 / \mathrm{m}], \mathrm{S}_{\mathrm{ha}}(=\mathrm{S} \cos \theta)$ : 正対面積 $\left[\mathrm{m}^{2}\right], \mathrm{S}$ : 標識表示面 の面積 (内容記載部の方形面積) $\left[\mathrm{m}^{2}\right], \theta$ : 水平角 $\left.\left[{ }^{\circ}\right]\right)$ 。

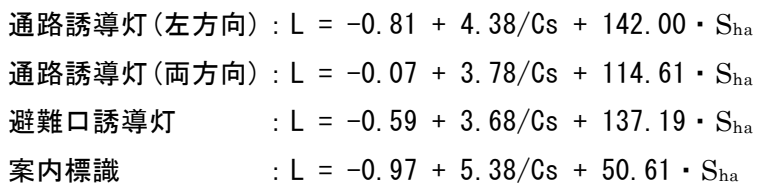

ただし、有効とする水平角 $\theta$ の範囲は $0^{\circ} \sim 80^{\circ}$ とする。本実験 の状況から、本式は算出される視認距離 $\mathrm{L}$ が $15 \mathrm{~m}$ 以下の範囲で 妥当に推定できる。加えて、視認距離 L が $15 \mathrm{~m}$ を超える場合は、 少なくとも視認距離は $15 \mathrm{~m}$ 以上であることを確認できる。

・予測式により視認距離を精度よく算出できる減光係数の範囲は 通路誘導灯（左方向）で $0.33[1 / \mathrm{m}]$ 以上、通路誘導灯（両方向） で $0.29[1 / \mathrm{m}]$ 以上、避難口誘導灯で $0.28[1 / \mathrm{m}]$ 以上、案内標識で $0.38[1 / \mathrm{m}]$ 以上となる。

・不慣れな人が避難し始めるとされる減光係数 $0.1[1 / \mathrm{m}]^{13)}$ で、標識の種 類、水平角に関わらず $15 \mathrm{~m}$ から全てが視認できることが推定された。

・建物をよく知っている人でも避難に支障が出るとされる減光係数 $0.3[1 / \mathrm{m}]{ }^{13}$ ) においては、通路誘導灯（左方向）の $70^{\circ}$ 及び $80^{\circ}$ と通路誘導灯（両方向）及び避難口誘導灯の全水平角において、 $15 \mathrm{~m}$ からは視認できないことが示唆された。

・求めた予測式により、水平角 $0^{\circ}$ の場合、消防法に規定される誘 導灯の有効範囲（通路誘導灯：10m、避難口誘導灯 $15 \mathrm{~m}$ ）におい て、建物をよく知っている人でも避難に支障が出るとされる減光 係数 $\left.0.3[1 / \mathrm{m}]{ }^{13}\right)$ においても、避難に使用できることが示唆された。

\section{3 今後の展望}

今後は、異なる表示面面積や輝度、照明の種類や照度基準の異なる 空間、黒煙の様な異なる成分の煙に関寸る既存もしくは今後の研究成果 を用いることで、本報の予測式の適用範囲を広げる必要性がある。加え て、実験での誘導灯の設置箇所は眼高より上部の天井付近である。床面 や足下に設置された誘導灯の視認性については把握の余地がある。

本研究は神による既往研究 ${ }^{1}$ と類似の範囲の研究であり、室内照明が 通常時点灯の場合には標識の視認限界時の輝度対比を一定として視認 限界距離の計測を行っても誤差は少ない一定条件下での研究成果を示 しているが、停電等により周辺光が低下した状況も含めて散乱光の重畳 による視認性への影響については検討の余地がある。

回帰式では、現実の状況において説明変数となりうる要素を取捨 選択し、選択した説明変数の中からさらに効果のある変数を採択す る。上述した煙の種類や表示面面積といった他の要素に関するデー 夕を追加実験や実験条件増加によって取得し、要素間における説明 変数の独立性の確保ができれば、多様な説明変数を含めた予測式を 導出できる可能性はある。しかしながら、変数の増加は、多重共線 性発生確率の増加、式全体の決定係数の上昇とそれを防ぐための実 験サンプル数の増加に繋がる。実験条件と実験サンプルの増加につ いては、被験者への負担が増加することから、限界がある。本報の 予測式を核とし、関連性が高くかつ実務上管理可能となる適切な数 の要因を選択することで各状況への対応が可能となると考えられる。

\section{参考文献}

1）神 忠久 : 煙中の誘導標識の見透し距離について（I）, 日本建築学会論 文報告集，第 182 号，pp.21-32，1971. 4

2) 神 忠久 : 煙中の誘導標識の見透し距離について（II ), 日本建築学会論 文報告集，第 192 号, pp.41-47, 1972.2

3）神 忠久 : 煙中の誘導標識の見透し距離について (III), 日本建築学会論 文報告集，第 204 号，pp.47-53，1973. 2

4) 山田常圭 : 煙中における誘導灯及び各種照明器具の見透し距離(その 1$)$, 新旧避難口誘導灯の比較, 日本建築学会大会学術講演梗概集, A-2, pp.139-140，2002.8

5）森山修治ほか：大規模地下街における避難行動特性に関する実験研究， 実験概要と避難経路・避難出口の選択性, 日本建築学会環境系論文集, 第 637 号, pp.233-240, 2009. 3

6) 田中孝治, 加藤隆: 避難口誘導灯に通過後の情報を付加することの効果, 心理学研究, 第 83 巻, 第 3 号, pp.182-192, 2012. 8

7）横石めぐみ, 林田和人, 渡辺仁史 : 暗視下における高輝度蓄光材を用い た避難行動特性に関する研究, 日本建築学会関東支部研究報告集 II, pp.53-56, 2007. 2

8）秋月有紀，岩田三千子，奥田紫乃，田中哮義：立体角投射率を用いた避 難経路のサイン設置状況の把握 -円滑な避難誘導のための視環境計画 に関する研究 その 1-, 日本建築学会環境系論文集, 第 641 号, pp.767-773, 2009. 7

9）石井弘允ほか：高輝度誘導灯の斜め方向からの見え方に関する評価実験 報告書, 社団法人 日本照明器具工業会, 2000.3

10)藤井皓介ほか: 煙中における案内標識及び誘導灯の視認距離、平成 24 年度日本火災学会研究発表会梗概集，B26, pp.152-153, 2012.5

11)藤井皓介ほか: 視方向に対する標識水平角の鋭角時における視認距離に 対する影響 一煙中における案内標識及び誘導灯の視認距離 その $2-$, 平 成 25 年度日本火災学会研究発表会梗概集, PS2, pp.354-355, 2013. 6 12) 日本規格協会：JIS A 1306:1983 減光法による煙濃度の測定方法, 1983 13)室崎益輝著 : 現代建築学 建築防災 - 安全, 鹿島出版会, 2000.1

注

注 1）誘導灯は機能により、避難口誘導灯、通路誘導灯、階段通路誘導灯、客 席誘導灯の 4 種類に分類される。本研究では、避難時の経路及び出口を 提示する避難口誘導灯と通路誘導灯に着目寸る。 
注 2) 避難経路における煙の滞留を想定した誘導灯の設置基準の見直し(平成 21 年 12 月 1 日施行）：消防法施行規則の一部改正（平成 21 年 9 月 30 公布）により、カラオケボックスや個室ビデオ店などの個室型店舗や地 下街など（消防法施行令別表第一 2 項二、16 項、16 の 2 項、16 の 3 項に掲げる防火対象の用途に供される部分）では煙の滞留が想定される ため、通路誘導灯を床面またはその直近に設置することが明記された。 合わせて、床面又はその直近部分に高輝度畜光式誘導標識を追加で設置 することによっても代替できる様になった（同規則第 28 条の 3 第 4 項 第 3 号の 2 関係)。駅舎については、通路誘導灯が視線上部に設置され る場合がある。ただし、駅舎（消防法施行令別表第一 10 項に掲げる防 火対象の用途に供される部分）を含めた一部の防火対象物については、 非常電源で 60 分間以上点灯可能な誘導灯の設置義務と高輝度蓄光式誘 導標識の併設による 20 分間以上点灯可能な誘導灯の据え置きの許可が 記載されている。乗降場が地階にあるものが対象となり、乗降場とそれ に通じる階段・通路も設置義務が生じる。床面積 $50000 \mathrm{~m}^{2}$ 以上の防火 対象物(2)地上階の階数が 15 以上階であるとともに床面積 $30000 \mathrm{~m}^{2}$ 以上 の防火対象物(3)床面積 $1000 \mathrm{~m}^{2}$ 以上の地下街が対象となる。

注 3）本研究における視認距離は、標識の文字及びピクトグラムを判読・識別 できる認知距離とする。案内標識については表示面にある矢印の方向と 文字、誘導灯についてはピクトグラムの判別ができるものとする。

注 4) 本研究では、現実の誘導灯の配置状況に類似する通路を想定したため、 蛍光灯を連続的に配置した空間において実験を実施した。照明光点灯下 における実験であることから、煙粒子により被験者の目に届く標識から の光が減少することに加えて、散乱することで被験者の目に届く照明に よる光が標識及び背景の輝度に重畳されるために標識と背景の輝度の 差が小さくなる。これにより、背景と標識の区別が無煙状態の時よりも しづらくなると考えられる。廊下または室内の一部を模した実験空間に より実施した既往の実験 1)において、室内照明が通常時点灯の場合には 標識の視認限界時の輝度対比を一定として視認限界距離の計測を行っ ても誤差は少ないとしている。本実験は、照明光の強さを通常時点灯の 範囲内としており、煙の質、背景輝度、標識の輝度、照明光の強さを固 定している。

注 5）測定において代表となる減光計の位置は、水平方向について、誘導灯正 面と実験空間中央付近とし、実験 1 と 2 ともに同位置である。スタート 地点の変更に伴いスタート地点に合わせて変更したが、水平位置間にお ける減光係数の計測值の差は小さいことを確認した。また、代表となる 測定点の精度を高めるためにその間の部分を補完的に計測した。その上 で近傍の測定点のデータが近いことを確認できたため、減光係数につい ては近傍のもの同士を平均した値を用いている。

注 6）駅舎通路を想定し、JIS Z 9110 照明基準総則において規定される駅舎 通路における照度に合わせた。JIS Z $9110 ： 2010$ 照明基準総則におい て維持照度及び照度均斉度、JIS Z $9110 ： 2011$ 照明基準総則(追補 1)に おいて照度範囲を規定している。駅舎の照度基準は 1 日の乗降客数によ り異なる。通路の維持照度は $\mathrm{A}$ 級駅、 $\mathrm{B}$ 級駅、 $\mathrm{C}$ 級駅の順に 200、100、 $751 \mathrm{x}$ 、照度均斉度は 3 駅ともに 0.4 となる。実験空間における平均照度 114lx は、B 級駅の照度範囲 75 150lx を満たすとともに、A 級駅に求 められる照度の最小值を満たすものである。大規模駅は $\mathrm{A}$ 級駅に含ま れる。大規模駅は空間が広く、加えて節電対策による照明が削減されて いるため、照度分布にばらつきが出ると考えられる。

注 7) 誘導灯及び案内標識の表示面の平均輝度と本実験における背景輝度を 下表に示す。いずれも煙のない初期状態における值である。なお、案内 標識については表示周辺の輝度を測定した。

\begin{tabular}{|c|c|c|}
\hline 標識 & 平均輝度 $\left[\mathrm{cd} / \mathrm{m}^{2}\right]$ & 背景輝度 $\left[\mathrm{cd} / \mathrm{m}^{2}\right]$ \\
\hline 通路誘導灯 (左方向) & 369 & 25 \\
\hline 通路誘䆃灯 (両方向) & 475 & 25 \\
\hline 避難口誘導灯 & 251 & 25 \\
\hline 案内標識 & 472 & 25 \\
\hline
\end{tabular}

注 8) 実験 1 については実験試行の繰り返しに伴い、減光計の測定電圧が低減 する状況が見られたため、減光係数の変化を一様増加と仮定した補正值 を用いている 10)。

注 9）回帰診断（Diagnostic Regression Analysis）は、少数のデータの影響 によるモデルの歪みをモデル自身に評価させることでデータ構造を把 握するものであり、データ診断、構造診断、モデル診断に分類される。 デー夕診断では、説明変数と目的変数、両方の外れ值を求める。構造診 断では、変数選択と多重共線性の把握を行う。モデル診断では、残差分 析によりデータの構造とモデルの形の整合性を把握する。
注 10）交互作用項は、主効果の中心化もしくは標準化により主効果との多重 共線性を解消寸ることができるが、中心化や標準化により要因の偏回帰 係数の有意確率に変化はない。並びに交互作用投入前後の決定係数の変 化及び要因の偏回帰係数と VIF から交互作用項の効果を判断できる。

注 11)参考文献 13)を参考とし、減光係数と対応寸る視認状況を以下に示寸。

\begin{tabular}{|c|c|}
\hline 減光係数 $(1 / \mathrm{m})$ & 状況説明 \\
\hline 0.1 & 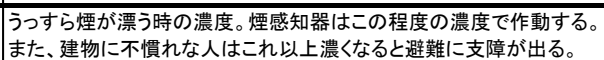 \\
\hline 0.3 & 建物を良く知っている人でも避難する時に支障が出る。 \\
\hline 0.5 & 薄暗い感しがする時の濃度。手探り的な避難にたなる。 \\
\hline 1.0 & ほとんど前方が見えなくなる。 \\
\hline 10 & 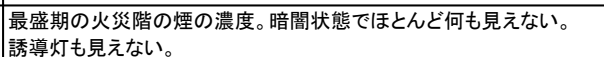 \\
\hline
\end{tabular}

（2013年11月10日原稿受理，2014年 4 月23日採用決定） 